Arch. Tierz., Dummerstorf 44 (2001) 1, 109-113

'Departunent of Animal \& Poultry Science, University of Guclph, Canada
${ }^{2}$ Hybrid Turkeys, Kitchener, Ontario, Canada

HOWARD J. SWATLAND', BETHANY UTTARO', JEFF MOHR ${ }^{2}$ and NICO BUDDIGER ${ }^{2}$

\title{
Relationships between electrical impedance and fluid losses from turkey breast meat
}

\begin{abstract}
Summary
Breast muscles were removed from turkeys soon after slaughter. The meat quality was judged to be normal with little or no evidence of the pale, soft, exudative (PSE) condition. Fluid losses the day after slaughter were 0.50 SD $0.35 \%$. The most reliable predictor of fluid losses was resistance: $r=-0.37$ at $120 \mathrm{kHz},-0,30$ at $\mathrm{I} \mathrm{Hz}$ and -0.34 at $10 \mathrm{kHz}(\mathrm{P}$ $<0,001, \mathrm{n}=156$ ). Between 1 and 4 days post-mortem, the mean drip loss from slices of turkey meat in a cooler was $4.31 \mathrm{SD} 1.91 \%$. Resistance was correlated with cooler drip loss : $r=-0.61$ at $120 \mathrm{~Hz},-0.51$ at $1 \mathrm{kHz}$ and -0.62 at 10 $\mathrm{kHz}(\mathrm{P}<0.00 \mathrm{I}, \mathrm{n}=45)$.
\end{abstract}

Key Words. Turkey meat, fluid losses, $\mathrm{pH}$ value, electrical impedance

\section{Zusammenfassung}

Titel der Arbeit: Beziehungen zwischen elektrischer Impedanz und Flässigkeitsverlust im Brustmuskel von Puten

Unmittelbar nach der Schlachtung in einem Schlachthof erfolgte bei 156 Puten die Entnahme des Brustmuskels. Beurteilt wurden in unterschiedlichen Zeitabstănden $\mathrm{pH}$-Wert, der Flassigkeitsverlust des Muskelgewebes sowie der Impedanzwert bei unterschiedlichen Frequenzen.. Die Fleischqualitat der Muskelscheiben wurde als normal beurteilt mit keinem oder nur geringem PSE Anteil. Der Flussigkeitsverlust nach dem Probentransport 24 h post mortem betrug 0,50 SD, 0.35\%. Der pH-Wert lag bei 5,97 SD, $0.11 \%$. Eindeutige Aussagen aber die Beziehungen des Flüssigkeitsverlustes zur Impedanzmessung ergaben Korrelationskoeffizienten von $r=-0.37$ bei $120 \mathrm{~Hz},-0,30$ bei 1 $\mathrm{kHz}$ und $-0,34$ bei $10 \mathrm{kHz}(\mathrm{p}<0,001)$. Zwischen dem 1. und 4. Tag post mortem betrug der Dripverlust der gekiuhlten Fleischproben im Mittel 4,31 SD, 1,191\%. Die Beziehung des Impedanzwertes zum Kuhlverlust betrug $\mathrm{r}$ $=-0,61$ bei $120 \mathrm{~Hz},-0,51$ bei I $\mathrm{kHz}$ und $-0,62$ bei $10 \mathrm{kHz}(\mathrm{p}>0,00 \mathrm{I}, \mathrm{n}=45)$.

Schlïsselwörter: Putenfleisch, Wasserverlust, pH-Wert, elektrische Impedanz.

\section{Introduction}

The pale, soft, exudative (PSE) condition caused by accelerated and/or prolonged postmortem glycolysis is a well known defect in the quality of pork. It causes commercially important fluid losses (BENDALL and SWATLAND, 1988). PSE is also a concern in poultry meat (VANDERSTOEP and RICHARDS, 1974; WOOD and RICHARDS, 1975; FRONING et al., 1978; VAN HOOF, 1979; McCURDY et al., 1996; BARBUT, 1996; SANTÉ et al, 1996; OWENS et al., 2000). An on-line predictor of fluid losses would be useful for turkey breeders and those responsible for capture, transport, slaughter and secondary processing. Turkey muscle with a rapid rate of post-mortem glycolysis has a low electrical impedance (ABERLE et al., 1971). Research was undertaken to evaluate impedance as a predictor of fluid losses from turkey breast meat. 
Materials and methods

Impedance is the hypotenuse of a triangle where the base is resistance and the height is capacitance (capacitive reactance). Capacitance $\left(\mathrm{C}_{S}\right)$ and resistance $\left(R_{S}\right)$ may be resolved as a series circuit related to their equivalents in parallel as follows,

$$
\begin{aligned}
& \mathrm{R}_{\mathrm{S}}=\mathrm{R}_{\mathrm{P}} /\left(1+\left(2 \pi f \mathrm{C}_{\mathrm{P}} \mathrm{R}_{\mathrm{P}}\right)^{2}\right. \\
& \mathrm{C}_{\mathrm{S}}=\mathrm{C}_{\mathrm{P}}\left(1+\left(1 /\left(2 \pi f \mathrm{C}_{\mathrm{P}} \mathrm{R}_{\mathrm{P}}\right)^{2}\right)\right.
\end{aligned}
$$

The parallel model is probably the best because it represents muscle fibres insulated to varying degrees by their cell membranes, all surrounded by extracellular fluid augmented to varying degrees by fluid released from the myofilament lattice (SWATLAND, 1995). When capacitance in parallel $\left(C_{p}\right)$ and resistance in parallel $\left(R_{p}\right)$ are related to frequency (f), the quality factor $(\mathrm{Q})$ is defined as,

$$
\mathrm{Q}=2 \pi \mathrm{fC}_{\mathrm{p}} \mathrm{R}_{\mathrm{p}}
$$

The other term in common use is the dissipation factor,

which is used in this report.

$$
\mathrm{D}=1 / \mathrm{Q}
$$

Measurements were made at three frequencies $(120 \mathrm{~Hz}, 1 \mathrm{kHz}$ and $10 \mathrm{kHz})$ with a commercial impedance bridge (LCR 4262A, Hewlett-Packard, Palo Alto, California) operated through a bus (IEEE 488). The electrodes were two stainless-steel needles with a diameter of $1.5 \mathrm{~mm}$. The needles were parallel, with an axial separation of $11 \mathrm{~mm}$. They penetrated the meat to a depth of $11 \mathrm{~mm}$. The pair of needles was inserted so that the axis between the needles was parallel with the long axes of the muscle fibres. In other words, measurements were taken along the muscle fibres.

Turkeys $(n=156)$ were slaughtered in a commercial plant. The birds were the by-product of a proprietary experiment to measure the heritability of meat quality in turkeys. The meat was typical of that produced commercially at the present time in Canada. Breast muscles from one side were packed in plastic bags and shipped to the University of Guelph. All measurements were made on the pectoralis. The transport fluid loss (including overnight storage) was found from the weight of the sample versus the fluid in the bag when opened 24 hours post-mortem. At this time, sample $\mathrm{pH}$ was measured with a Cole-Parmer spear-tip, glass-body, combination electrode with a $\mathrm{Ag} / \mathrm{AgCl}$ reference cell. Sample temperature at the time of measurement was approximately $6^{\circ} \mathrm{C}$. Paleness was measured with a Minolta Chromameter CR-200b, using CIE L' as the measure of paleness. Two paleness measurements were made and averaged. For a sub-group of samples $(n=45)$, the cooler drip was found from $30-\mathrm{g}$ slices suspended in cotton bags inside inflated plastic bags in a meat cooler at $4^{\circ} \mathrm{C}$ for a further 72 hours. Programs for statistical testing were adapted from STEEL and TORRIE (1980), using least-squares linear regressions for a simple coefficient of correlation.

\section{Results}

The mean transport fluid loss between slaughter and laboratory testing at 24 hours postmortem was $0.50 \mathrm{SD} 0.35 \%$. The mean $\mathrm{pH}$ was $5.97 \mathrm{SD} 0.11$. Transport loss was correlated with $\mathrm{pH}, \mathrm{r}=-0.29, \mathrm{P}<0.001$. The mean value for paleness was $\mathrm{L}^{*}=45.15 \mathrm{SD}$ 
Arch. Tierz. 44 (2001) I

1.87. Paleness was correlated with $\mathrm{pH}(\mathrm{r}=-0.16, \mathrm{P}<0.05)$ and with transport loss $(\mathrm{r}=$ $0.17, \mathrm{P}<0.05)$.

Table 1

Impedance measurements in relation to transport fluid loss $(n=156)$ (Impedanzmessung in Beziehung zum Transportverlust)

\begin{tabular}{|c|c|c|c|}
\hline Impedance measurement & Mean (SD) & $\begin{array}{l}r \text {, versus transport } \\
\text { fluid loss }\end{array}$ & $r$, versus $\mathrm{pH}$ \\
\hline $120 \mathrm{~Hz}$ capacitance, $\mathrm{F}$ & $\begin{array}{l}6.85 \mathrm{E}-6 \\
(8.64 \mathrm{E}-7)\end{array}$ & $0.15^{2}$ & $-0.20^{b}$ \\
\hline $120 \mathrm{~Hz}$ resistance, $\Omega$ & $\begin{array}{l}2.23 \mathrm{E}+2 \\
(3.23 \mathrm{E}+1)\end{array}$ & $-0.37^{d}$ & $0.24^{6}$ \\
\hline $120 \mathrm{HzD}$ & $\begin{array}{l}2.24 \mathrm{E}+2 \\
(3.22 \mathrm{E}+1)\end{array}$ & $-0.37^{d}$ & $0.24^{c}$ \\
\hline I kHz capacitance, $\mathrm{F}$ & $\begin{array}{l}1.16 \mathrm{E}-6 \\
(8.44 \mathrm{E}-7)\end{array}$ & 0.02 & 0.12 \\
\hline $1 \mathrm{kHz}$ resistance, $\Omega$ & $\begin{array}{l}1.61 \mathrm{E}+2 \\
(4.00 \mathrm{E}+1)\end{array}$ & $-0.30^{d}$ & $0.22^{e}$ \\
\hline $1 \mathrm{kHz} \mathrm{D}$ & $\begin{array}{l}1.52 \mathrm{E}+2 \\
(2.73 \mathrm{E}+1)\end{array}$ & $-0.33^{d}$ & $0.19^{6}$ \\
\hline $10 \mathrm{kHz}$ capacitance, $\mathrm{F}$ & $\begin{array}{l}8.85 \mathrm{E}-7 \\
(5.52 \mathrm{E}-7)\end{array}$ & $0.38^{4}$ & $-0.22^{\circ}$ \\
\hline $10 \mathrm{kHz}$ resistance, $\Omega$ & $\begin{array}{l}1.28 E+2 \\
(2.18 E+1)\end{array}$ & $-0.34^{d}$ & $0.18^{n}$ \\
\hline $10 \mathrm{kH} z \mathrm{D}$ & $\begin{array}{l}1.28 \mathrm{E}+2 \\
(2.17 \mathrm{E}+1)\end{array}$ & $-0.34^{d}$ & $0.18^{\circ}$ \\
\hline
\end{tabular}

${ }^{\mathrm{a} p}<0.05,{ }^{\mathrm{b}} \mathrm{p}<0.01,{ }^{\mathrm{C}} \mathrm{p}<0.005,{ }^{\circ} \mathrm{p}<0.001$

Mean values for impedance measurements and their relationships with transport fluid loss and $\mathrm{pH}$ are shown in Table 1. In the sub-group tested for drip loss in the cooler (for 72 hours, starting at 24 hours post-mortem), the mean $\mathrm{pH}$ was $5.97 \pm 0.12$. The drip loss was $4.31 \pm 1.91 \%$. Cooler drip was correlated with $\mathrm{pH}, \mathrm{r}=-0.35, \mathrm{P}<0.02$. Transport fluid loss was correlated with cooler drip, $\mathrm{r}=0.47, \mathrm{P}<0.001$. Mean values for impedance measurements in the sub-group and their relationships with cooler drip loss are shown in Table 2.

Table 2

Impedance measurements in relation to cooler drip $(\mathrm{n}=45)$ (Impedanzmessung in Beziehung zum Kühlverlust)

\begin{tabular}{llc}
\hline Impedance measurement & Mean $(\mathrm{SD})$ & r, versus cooler drip \\
\hline $120 \mathrm{~Hz}$ capacitance, $F$ & $6.87 \mathrm{E}-6(8.26 \mathrm{E}-7)$ & $0.28^{\mathrm{d}}$ \\
$120 \mathrm{~Hz}$ resistance, $\Omega$ & $2.23 \mathrm{E}+2(3.12 \mathrm{E}+1)$ & $-0.61^{\mathrm{d}}$ \\
$120 \mathrm{~Hz} \mathrm{D}$ & $2.23 \mathrm{E}+2(3.12 \mathrm{E}+1)$ & $-0.61^{\mathrm{d}}$ \\
$1 \mathrm{kHz}$ capacitance, $\mathrm{F}$ & $1.12 \mathrm{E}-6(8.21 \mathrm{E}-7)$ & 0.19 \\
$1 \mathrm{kHz}$ resistance, $\Omega$ & $1.60 \mathrm{E}+2(4.13 \mathrm{E}+1)$ & $-0.51^{\mathrm{d}}$ \\
$1 \mathrm{kHz} D$ & $1.49 \mathrm{E}+2(2.54 \mathrm{E}+1)$ & $-0.60^{\mathrm{d}}$ \\
$10 \mathrm{kHz}$ capacitance, F & $8.87 \mathrm{E}-7(5.46 \mathrm{E}-7)$ & $0.57^{\mathrm{d}}$ \\
$10 \mathrm{kHz}$ resistance, $\Omega$ & $1.27 \mathrm{E}+2(2.14 \mathrm{E}+1)$ & $-0.62^{\mathrm{d}}$ \\
$10 \mathrm{kHz} \mathrm{D}$ & $1.27 \mathrm{E}+2(2.14 \mathrm{E}+1)$ & $-0.62^{\mathrm{d}}$ \\
\hline
\end{tabular}

$10 \mathrm{kHz} \mathrm{D}$

${ }^{4} \mathrm{P}<0.05,{ }^{\mathrm{b}} \mathrm{p}<0.01,{ }^{\mathrm{P}} \mathrm{P}<0.005,{ }^{\mathrm{d}} \mathrm{P}<0.001$

\section{Discussion}

The most important point to note is that, relative to the previous studies on PSE turkey meat cited earlier, the means for fluid loss, paleness and $\mathrm{pH}$ indicate that there were few, 
if any, severe cases of PSE in the population examined here. For example, OWENS et al. (2000) measured the paleness of turkey breasts at 24 hours post-mortem with a similar colorimeter to that used here and found the L* for PSE meat was 54.72 while the L* for normal meat was 48.99 . In the samples examined here, the mean value for paleness was $\mathrm{L}^{*}=45.15$, which is even darker than the normal meat of OWENS et al. (2000). Similarly, the mean $\mathrm{pH}$ of the samples examined here $(\mathrm{pH}=5.97)$ was closer to the mean $\mathrm{pH}$ for the normal samples ( $\mathrm{pH}$ 6.09) than to the PSE samples ( $\mathrm{pH} 5.72$ ) examined by OWENS et al. (2000). The relatively narrow range of the normal samples of turkey meat described here probably explains why correlations of paleness with transport fluid loss were relatively weak $(\mathrm{r}=0.17)$. Within this narrow range, impedance measurements were more useful than $\mathrm{pH}$ or paleness in predicting fluid losses (Tables 1 and 2).

However, the impedance results were not entirely as expected from previous experience with pork. BANFIELD (1935) discovered that $\mathrm{pH}$-dependent aspects of pork quality, such as PSE, could be monitored on-line using electrical conductivity measured with an alternating current $(1 \mathrm{kHz})$. Resistance was high in dry pork and low in wet pork. This has been confirmed by numerous investigators using a variety of commercial conductivity meters (SWATLAND, 1995). Capacitance measurements were introduced for PSE detection in pork to avoid the strong effect that sample temperature has on resistance (SWATLAND, 1980). Numerous factors may cause sample temperature to vary in pork, such as back-fat thickness insulating the carcass against heat uptake during scalding or heat loss during early refrigeration. Capacitance was only slightly affected by extremes of temperature, and was high in dry pork and low in wet pork. Thus, capacitance was positively correlated with $\mathrm{pH}$, because PSE pork with a low $\mathrm{pH}$ had low capacitance and vice versa. Dielectric loss factor was introduced to facilitate automated measurement of electrical impedance in meat (PFÜTZNER and FIALIK, 1982). As expected from resistance and capacitance, the dielectric loss factor was high in normal
pork and low in PSE pork.

It is of interest to note, therefore, that the significant relationships for capacitance shown in Table 1 are opposite in sign to those expected. For example, at $10 \mathrm{kHz}$, transport fluid loss unexpectedly had a positive correlation with capacitance whereas, as expected, transport fluid loss had negative correlations with resistance and D. Was this because the electrical measurements were made after the transport fluid loss had occurred? Perhaps, but the same pattern in the sign of the correlations was found for cooler drip losses measured between 1 and 4 days post-mortem, as shown in Table 2 . Further evidence of this anomalous relationship between capacitance and fluid losses may be seen from the correlations of capacitance with $\mathrm{pH}$ in Table 1 , which are negative rather than positive in
sign.

In summary, this simple experiment undertaken to find a suitable frequency at which to predict fluid losses on-line produced an entirely unexpected result for capacitance, which is why resistance is recommended for the prediction of fluid losses. Further studies are planned to seek an explanation for the anomalous results for capacitance. Possibly there is some non-linearity in the relationship of capacitance and tissue fluid distribution. A complete survey of different electrode orientations and sampling times post-mortem in a population including severely PSE meat is required. 


\title{
References
}

ABERLE, E.D.; STADELMAN, W.J.; ZACHARIAH, G.L.; HAUGH, C.G.:

Impedance of turkey muscle: relation to post mortem metabolites and tenderness. Poultry Sci, 50 (1971), 743-746

BANFIEL,D, F.H.:

The electrical resistance of pork and bacon. Part I. Method of measurement. J. Soc. Chem. Ind, 13 (1935), 411-413.

\section{BARBUT, S.:}

Estimates and detection of the PSE problem in young turkey breast meat. Can. J. Anim. Sci., 76 (1996), 455-457

BENDALL, J.R.; SWATLAND, H.J.:

A review of the relationships between $\mathrm{pH}$ and physical aspects of pork quality, Meat Sci., 24 (1988), 85 126

FRONING, G.W.; BABJI, A.S.; MATHER, F.B.:

The effect of preslaughter temperature, stress, struggle and anesthetization on color and textural characteristics of turkey muscle. Poultry Sci., 57 (1978), 630-633

McCURDY, R.D.; BARBUT, S.; QUINTON, M. Seasonal effect on pale soft exudative (PSE) occurrence in young turkey breast meat. Food Res. Internat, 29 (1996), 363-366

OWENS, C.M.; HIRSCHLER, E.M.; MCKEE, S.R.; MARTINEZ-DAWSON, R.; SAMS, A.R.;

The characterization and incidence of pale, soft, exudative turkey meat in a commercial plant. Poultry Sci., 79 (2000), 553-558.

PFÜTZNER, H.; FIALIK,E.:

A new electrophysical method for the detection of exudative porcine muscle. Zbl. Vet. Mad. A., 29 (1982), $637-645$

SANTÉ, V.S.; LEBERT, A.; Le POTTIER, G.; OUALI, A.:

Comparison between two statistical models for prediction of turkey breast meat colour. Meat Sci., 43 (1996), 283-290

STEEL, R.G.D.; TORRIE, J.H.:

Principles and Procedures of Statistics. A Biometrical Approach. 2nd edit. McGraw-Hill, New York. 1980

SWATLAND, H.J.: On-line Evaluation of Meat. Technomic Press, Lancaster, Penusylvania. 1995

SWATLAND, H.J::

Postmortem changes in electrical capacitance and resistivity of pork. J. Anim. Sci., 51 (1980), $1108-1112$

VANDERSTOEP, J.; RICHARDS, J.F.:

Post-mortem glycolytic and physical changes in turkey breast muscle. Can. Inst, Food Sci. Technol. J., 7 (1974), 120-124

VAN HOOF, J.:

Influence of ante- and peri-mortem factors on biochemical and physical characteristics of turkey breasi muscle. Vet. Quart., 1 (1979), 29-36

WOOD, D.F.; RICHARDS, J.F.:

Effect of some antemortem stressors on postmortem aspects of chicken broiler pectoralis muscle. Poultry Sci., 54 (1975), 528-531

\author{
Received; 2000-05-31 \\ Accepted: 2000-10-11 \\ Author's address \\ Prof. H.J. SWATLAND \\ Department of Animal \& Poultry Science \\ University of Guelph, \\ Guelph, Ontario NIG 2WI \\ Canada \\ Tel: (519) 824-4120 ext 3670 \\ Fax: (519) 767-0573 \\ E-Mail: HSWATLAND@APS.UOGUELPH.CA
}


Arch. Tierz., Dummerstorf $\$ 4$ (2001) I, 114

\section{TAGUNGSANKÜNDIGUNGEN}

The $8^{\text {th }}$ International Congress on Biotechnology in Animal Reproduction (ICBAR)

Management of reproduction in

cattle and pigs - physiological background and application

Bernburg, Saxony-Anhalt, Germany,

September, 24 to 26,2001

\section{Organizers}

Anhalt University of Applied Sciences

Research lnstitute for the Biology

Bernburg, Germany

of Farm Animals

Faculty of Agriculture, Ecotrophology,

Dummerstorf, Germany

Land Management

Prof. Dr. agr, Martin Wahner

Strenzfelder Allee 28

D-06406 Bemburg

e-mail: wachmer@oloel.hs-anlialt.de

Deparument of Reproductive Biology

VR Dr. med, vet. Wilhelm Kanitz

Wilhelm-Stahi-Allee 2

D-18196 Dummerstorf

e-mail: wkanitz@ufbu-dummerstorf.de

\section{Conference Office}

Anhalt University of Applied Sciences

Strenzfelder Allee 28

D-06406 Bermburg

\section{S. Thalmann}

Telephone:

Telefax:

$$
+493471355-434
$$

e-mail:

\section{Scientific Program}

- Follicular development and ovulation

- C.I. function

- Sperm function

- Synchronization of oestrus and ovulation

- In vitro fertilization and cloning

- Efficient use of bulls and boars for A.I.

- Induction and synchronization of parturition

\author{
A. John \\ Telephone: $\quad+493471355-471$ \\ Telefax: $+493471352-967$ \\ e-mail: ajohnouloel.hs-anhalide
}

\section{Kulmbacher Woche}

\section{8. bis 9. Mai 2001}

Veranstalter: Bundesanstalt für Fleischforschung

In der Zeit vom 8. bis 9. Mai 2001 (Beginn $8.30 \mathrm{Uhr}$, Stadthalle Kulmbach) findet die 36. Kulmbacher Woche statt. Mit nur zwei Tagen Dauer wurde die Tagung neu konzipiert und unter Erhaltung der gewohnten Informationsfulle zeitlich konzentriert.

Die insgesamt 17 Vortrăge greifen Themen der Lebensmittelsicherheit, der allgemeinen Produktqualităt von Fleisch und Fleischwaren und methodische Fragen des Bereiches auf. Das Lebensmittelrechtliche Kolloquium schließt die Tagung ab.
Anmeldungen erfolgen bis zum 14. April 2001 an:
Bundesanstalt für Fleischforschung
E.-C.-Baumann-Straße 20
95326 Kulmbach

Tel. 09221/803-269

Fax: 09221 / 803-244

E-Mail: baff@compuserve.com 